\title{
Longispora fulva sp. nov., isolated from a forest soil, and emended description of the genus Longispora
}

Correspondence

Hatsumi Shiratori-Takano

siratori@brs.nihon-u.ac.jp

\author{
Hatsumi Shiratori-Takano, Koji Yamada, Teruhiko Beppu and Kenji Ueda
}

Life Science Research Center, College of Bioresource Sciences, Nihon University, 1866 Kameino, Fujisawa 252-0880, Japan

\begin{abstract}
A novel actinomycete, strain $K Z 0017^{\top}$, was isolated from a forest soil collected in Ohnuma, Fukushima, Japan. Strain KZ0017 ${ }^{\top}$ formed spore chains borne on top of short sporophores arising from vegetative hyphae. Spores were non-motile and cylindrical with smooth surfaces. Strain $\mathrm{KZO017}{ }^{\top}$ contained meso-diaminopimelic $\left(\mathrm{A}_{2} \mathrm{pm}\right)$ acid, 3-OH $\mathrm{A}_{2} \mathrm{pm}$, D-glutamic acid, glycine and L-alanine in the cell-wall peptidoglycan, and xylose, mannose, galactose, rhamnose and ribose in cell-wall hydrolysates. The acyl type of the cell-wall polysaccharides was glycolyl. The predominant menaquinones were $\mathrm{MK}-10\left(\mathrm{H}_{4}\right)$ and $\mathrm{MK}-10\left(\mathrm{H}_{6}\right) ; \mathrm{MK}-10\left(\mathrm{H}_{8}\right)$ was a minor component. The polar lipids contained diphosphatidylglycerol, phosphatidylethanolamine, hydroxyphosphatidylethanolamine, phosphatidylinositol and several unknown lipids and glycolipids. The major fatty acids were iso- $C_{16: 0}, 10-$ methyl $-C_{17: 0}$ and iso- $C_{17: 1} \omega 9 c$. The DNA $\mathrm{G}+\mathrm{C}$ content was $70.7 \mathrm{~mol} \%$. The $16 \mathrm{~S}$ rRNA gene sequence of the isolate formed a monophyletic cluster with the single member of the genus Longispora in the family Micromonosporaceae. On the basis of morphological, chemotaxonomic and phylogenetic properties, strain $\mathrm{KZ} 0017^{\top}$ represents a novel species of the genus Longispora, for which the name Longispora fulva sp. nov. is proposed; the type strain is $\mathrm{KZ} 0017^{\top}$ $\left(=\right.$ NBRC $105670^{\top}=$ DSM $\left.45356^{\top}\right)$.
\end{abstract}

The genus Longispora of the family Micromonosporaceae was proposed recently by Matsumoto et al. (2003) based on the identification of Longispora albida $\mathrm{K} 97-0003^{\mathrm{T}}$, the producer of an anti-HIV substance (Chiba et al., 2001, 2004). This genus is characterized by the presence of meso-diaminopimelic acid $\left(\mathrm{A}_{2} \mathrm{pm}\right)$, glycine and alanine in the cell wall, and arabinose, galactose and xylose in whole-cell hydrolysates. Longispora albida can be distinguished from members of other genera in the family Micromonosporaceae by its respiratory quinones [major, MK-10 $\left(\mathrm{H}_{4}\right)$ and MK-10 $\left(\mathrm{H}_{6}\right)$; minor, MK-10 $\left(\mathrm{H}_{8}\right)$ ] and phospholipids (type II). The organism shows better growth on gellan gum media than on agar media and forms characteristic spore chains consisting of cylindrical smooth spores on the top of short sporophores branching from vegetative hyphae. Phylogeny based on $16 \mathrm{~S}$ rRNA gene sequences clearly showed that Longispora is a novel genus within the family Micromonosporaceae. However, it currently contains only a single species, L. albida.

In our recent study on the diversity of high- $\mathrm{CO}_{2}$-dependent bacteria (Ueda et al., 2008), a filamentous bacterium

Abbreviations: $\mathrm{A}_{2}$ pm, diaminopimelic acid; ISP, International Streptomyces Project.

The GenBank/EMBL/DDBJ accession number for the 16S rRNA gene sequence of Longispora fulva KZO017 ${ }^{\top}$ is AB489859.

A supplementary table and figures are available with the online version of this paper.
$\left(\mathrm{KZ0017} 7^{\mathrm{T}}\right)$ was isolated from soil collected at a group of old zelkova trees (Zelkova serrata). Strain $\mathrm{KZ} 0017^{\mathrm{T}}$ produced a yellow ochre pigment and an antibiotic that inhibited growth of Bacillus subtilis when it was cultured under a high $(5 \%) \mathrm{CO}_{2}$ atmosphere. This report deals with the taxonomic characteristics of this isolate. Overall, the data indicate that this isolate represents a novel species of the genus Longispora.

The soil from which strain $\mathrm{KZ}_{0017^{\mathrm{T}}}$ was isolated was collected in a forest in Ohnuma, Fukushima Prefecture, Japan. For the isolation, $1.0 \mathrm{~g}$ soil sample was suspended in $20 \mathrm{ml}$ distilled water and, after serial dilution, plated on peptone-meat extract (PM) gellan gum medium [per litre distilled water: $0.1 \mathrm{~g}$ peptone (Wako), $0.1 \mathrm{~g}$ meat extract (Kyokuto), $0.05 \mathrm{~g} \mathrm{NaCl}, 1.5 \mathrm{~g} \mathrm{MgSO}_{4} \cdot 7 \mathrm{H}_{2} \mathrm{O}, 15.0$ g gellan gum (Wako), pH 7.5; chemicals were purchased from Kokusan unless indicated otherwise]. Plates were incubated at $28{ }^{\circ} \mathrm{C}$ for 2 weeks under a normal atmosphere or under a $5 \% \mathrm{CO}_{2}$ atmosphere using a $\mathrm{CO}_{2}$ incubator (model 5400; Napco). Despite the fact that strain $\mathrm{KZ}^{2} 0017^{\mathrm{T}}$ produced an antibiotic only under high $\mathrm{CO}_{2}$ conditions, it grew as well under normal air as under the high $\mathrm{CO}_{2}$ air. Hence, strain $\mathrm{KZ}_{0017^{\mathrm{T}}}$ was grown aerobically under a normal atmosphere for $4-35$ days at $28{ }^{\circ} \mathrm{C}$ on yeast extractmalt extract agar [International Streptomyces Project (ISP) 2 medium; Shirling \& Gottlieb, 1966], unless noted otherwise, to characterize its physiological properties. For storage, cells 
were maintained by using a Microbank (Pro-Lab Diagnostics) or as glycerol $(10 \%, \mathrm{v} / \mathrm{v}) /$ trehalose $(0.5 \%, \mathrm{w} / \mathrm{v})$ suspensions at $-80{ }^{\circ} \mathrm{C}$. L. albida $\mathrm{K} 97-0003^{\mathrm{T}}\left(=\mathrm{NBRC} 100759^{\mathrm{T}}\right)$ was used as a reference strain.

Cell morphology was observed under a VE-8800 scanning electron microscope (Keyence) using cells grown on ISP 2 medium and inorganic salts-starch agar (ISP 4 medium) for $1-5$ weeks at $28{ }^{\circ} \mathrm{C}$. For scanning electron microscopy, cells were fixed with $4.0 \%(\mathrm{v} / \mathrm{v})$ osmium tetroxide vapour. ISP media were prepared as described by Shirling \& Gottlieb (1966). Cultural and physiological characteristics were determined as described previously (Gordon et al. 1974; Hamada, 2001; Shirling \& Gottlieb, 1966). Growth of the isolate was assessed at various temperatures $(5,10,12$, $15,20,25,28,30,33,35,37$ and $\left.40{ }^{\circ} \mathrm{C}\right)$ and salinities [0, $0.4,0.8,1.0,1.2,1.4,1.5,2.0,4.0,7.0,10$ and $13 \%(\mathrm{w} / \mathrm{v})$ $\mathrm{NaCl}$ ] after cultivation for 5-10 days on ISP 2 medium $\left(\mathrm{NaCl}\right.$ plates were incubated at $\left.28{ }^{\circ} \mathrm{C}\right)$. The $\mathrm{pH}$ range for growth was assessed in ISP 2 broth at $28{ }^{\circ} \mathrm{C}$ at $0.5 \mathrm{pH}$ unit intervals between $\mathrm{pH} 5.0$ and 12.0 using $100 \mathrm{mM}$ citrate phosphate ( $\mathrm{pH} 5.0-5.5)$, sodium phosphate $(\mathrm{pH} 6.0-8.5)$, sodium carbonate ( $\mathrm{pH} 9.0-10.0)$ and sodium sesquicarbonate $/ \mathrm{NaOH}(\mathrm{pH} 10.5-12.0)$ buffers. Colours of the cultures were determined according to the Munsell Book of Color (Munsell Color Co. Inc., 1976) and A Mycological Colour Chart (Rayner, 1970). The Gram reaction was performed following the method described by Bartholomew \& Mittwer (1952). Acid-fastness was determined by using carbol-fuchsin solution for cell staining, acid alcohol treatment and counter-staining with methylene blue (Ziehl-Neelsen staining method).

Strain $\mathrm{KZ} 0017^{\mathrm{T}}$ exhibited good growth on ISP 2 medium, ISP 4 medium and glucose-peptone agar; moderate growth on oatmeal agar (ISP 3 medium), glycerol-asparagine agar (ISP 5 medium), glucose-asparagine agar, nutrient agar, water-proline agar ( $1 \%$ proline, tap water) and sucrosenitrate agar; poor growth on tyrosine agar (ISP 7 medium), glucose-nitrate agar, 1/10 V8 agar and 1/10 V8-calcium chloride agar (Matsumoto et al., 2003); and almost no growth on HV agar (Hayakawa \& Nonomura, 1989) or peptone-yeast extract-iron agar (ISP 6 medium). The colour of the colonies was light greyish olive (Munsell 5Y 6/8) on ISP 2, light greenish yellow (Munsell 7.5Y 9/4) on ISP 4, yellowish white (Munsell 5Y 9/3) on glucoseasparagine agar, olive-ochre (Munsell 5Y 6/6) on glucosepeptone agar, pale yellow (Munsell 2.5Y 9/2) on ISP 3, ISP 5 , nutrient agar, water-proline agar and sucrose-nitrate agar, and white on ISP 7, glucose-nitrate agar, 1/10 V8 agar and 1/10 V8-calcium chloride agar. Colonies on ISP 2 medium were solid and wrinkled with a wavy surface.

Cells of strain $\mathrm{KZ}_{0017^{\mathrm{T}}}$ were Gram-positive, non-acid-fast, aerobic and non-motile. Strain $\mathrm{KZ} 0017^{\mathrm{T}}$ formed spore chains on ISP 2 and ISP 4 media, glycerol-asparagine agar and sucrose-nitrate agar, but not on the other media described above. Short sporophores branched from the substrate mycelium. After 3 weeks cultivation on ISP 2 medium, straight chains of spores were formed on the top of sporophores (see Supplementary Fig. S1a, available in IJSEM Online). Spores were cylindrical $(0.25-0.35 \times 0.5-$ $0.75 \mu \mathrm{m}$ ) with a smooth surface. During the first 23 weeks of cultivation at $28{ }^{\circ} \mathrm{C}$, the morphology of strain $\mathrm{KZ} 0017^{\mathrm{T}}$ on ISP 4 medium was the same as that observed on ISP 2 medium in terms of the structure of mycelia and spore chains. However, after 4 weeks growth, a bundle-like structure of aerial hyphae was occasionally observed on ISP 4 (Supplementary Fig. S1b), but not on ISP 2 medium. Motile spores and sporangia were not observed.

Growth of strain $\mathrm{KZ} 0017^{\mathrm{T}}$ was observed at $10-33{ }^{\circ} \mathrm{C}$ (optimum, $28-30{ }^{\circ} \mathrm{C}$ ), at $\mathrm{pH}$ 6.0-8.5 (optimum, pH 6.57.5) and in $0-1.2 \%(\mathrm{w} / \mathrm{v}) \mathrm{NaCl}$. Strain $\mathrm{KZ}_{0} 017^{\mathrm{T}}$ utilized $(+)$-D-glucose, inositol and xylose and grew weakly on sucrose, but did not utilize $(+)$-L-arabinose, fructose, $(+)$-D-mannitol, melibiose, (+)-raffinose or rhamnose. Melanoid pigment and $\mathrm{H}_{2} \mathrm{~S}$ were not produced. Nitrate was not reduced. Hydrolysis of casein and starch was positive, but that of gelatin, cellulose, xylan and chitin was negative. Differences in physiological and biochemical characteristics between strain $\mathrm{KZ}^{\mathrm{T}} 0017^{\mathrm{T}}$ and L. albida K97- $0003^{\mathrm{T}}$ are summarized in Table 1.

Biochemical characterizations and determination of the DNA G $+\mathrm{C}$ content of strain $\mathrm{KZ}^{2} 017^{\mathrm{T}}$ were carried out using cells cultured in ISP 2 broth on a rocking shaker at $28{ }^{\circ} \mathrm{C}$ for $4-5$ days. DNA was extracted by using phenol/ chloroform extraction followed by polyethylene glycol precipitation, based on the method described by Hopwood et al. (1985) with some modifications as follows: crude achromopeptidase (Wako), $N$-acetylmuramidase SG (Seikagaku Kogyo) and lysozyme were used for lysing cells. The DNA G + C content of strain $\mathrm{KZ} 0017^{\mathrm{T}}$, determined by HPLC (Tamaoka \& Komagata, 1984), was 70.7 mol\% [mean of three measurements $(\mathrm{SD}=0.1)]$. Polar lipid extraction and identification were performed according to Komagata \& Suzuki (1987). Sugar- and choline-containing lipids were detected by using $p$-anisaldehyde reagent and Dragendorff reagent, respectively. The spots were identified by using a phospholipid kit (Funakoshi) as a standard. Menaquinones were determined by using the procedures of Nishijima et al. (1997). Fatty acid methyl esters were extracted and analysed according to the standard protocol of the Sherlock Microbial Identification System (version 4.5; MIDI) with the TSBA40 library. The cell wall was purified following the method of Kawamoto et al. (1981) and amino acids in the peptidoglycan were determined by TLC (Harper \& Davis, 1979). Whole-cell sugar patterns were analysed according to the method of Becker et al. (1965). Isomers of $A_{2} \mathrm{pm}$ and the acyl type of the peptidoglycan were determined by the methods of Hasegawa et al. (1983) and Uchida \& Aida (1977), respectively. The presence of mycolic acids was examined as described by Tomiyasu (1982).

The major cellular fatty acids of strain $\mathrm{KZ} 0017^{\mathrm{T}}$ were iso$\mathrm{C}_{16: 0}, 10$-methyl- $\mathrm{C}_{17: 0}$ and iso- $\mathrm{C}_{17: 1} \omega 9 c$ (see Supplementary Table S1, available in IJSEM Online), which accounted for 
Table 1. Diagnostic characteristics that differentiate strain $\mathrm{KZ} 0017^{\top}$ from Longispora albida K97-0003 ${ }^{\top}$

Taxa: 1, strain $\mathrm{KZ}_{0017^{\mathrm{T}}}$ (data from this study); 2, Longispora albida $\mathrm{K} 97-0003^{\mathrm{T}}$ [data from Matsumoto et al. (2003), except where marked]. +, Positive; -, negative.

\begin{tabular}{|lcc|}
\hline Characteristic & $\mathbf{1}$ & $\mathbf{2}$ \\
\hline Temperature range for growth $\left({ }^{\circ} \mathrm{C}\right)$ & $10-33$ & $12-37$ \\
Growth at pH 9.0 & - & + \\
Growth in $1.5 \%(\mathrm{w} / \mathrm{v}) \mathrm{NaCl}$ & - & + \\
Growth/colour on:* & & Good/yellowish white \\
ISP 2 & Good/light greyish olive & - \\
ISP 4 & Good/light greenish yellow & Moderate/pale yellow \\
ISP 6 & - & Moderate/white \\
Glucose-asparagine agar & Moderate/yellowish white & Poor/pale yellow \\
Glucose-peptone agar & Good/olive-ochre & - \\
Sucrose-nitrate agar & Moderate/pale yellow & - \\
Utilization of carbon sources: & & - \\
Inositol & + & 70 \\
Xylose & + & \\
DNA G + C content $($ mol\%) & 70.7 & \\
\end{tabular}

${ }^{*}$ Data for both strains from this study.

$68.8 \%$ of the total fatty acids of cells of strain $\mathrm{KZ} 0017^{\mathrm{T}}$ grown in ISP 2. A similar fatty acid profile was determined for $L$. albida $\mathrm{K} 97-0003^{\mathrm{T}}$ in this study (Supplementary Table S1, available in IJSEM Online). These profiles corresponded to fatty acid type $3 b$ according to Kroppenstedt (1985). Strain $\mathrm{KZ} 0017^{\mathrm{T}}$ could be differentiated from L. albida $\mathrm{K} 97-0003^{\mathrm{T}}$ by the absence of the saturated fatty acids $\mathrm{C}_{15: 0}, \mathrm{C}_{17: 0}$ and $\mathrm{C}_{19: 0}$ and the unsaturated fatty acid iso- $\mathrm{C}_{18: 1} \mathrm{H}$ (Supplementary Table S1). Strain KZ0017 ${ }^{\mathrm{T}}$ contained diphosphatidylglycerol, phosphatidylethanolamine, hydroxyphosphatidylethanolamine, phosphatidylinositol, three unknown lipids (L1, L2 and L3) and unknown glycolipids (GLs). Phosphatidylcholine and phospholipids containing glucosamine were not detected (Supplementary Fig. S2a, available in IJSEM Online). The polar lipid pattern of strain $\mathrm{KZ}_{0017^{\mathrm{T}}}$ was similar to that of $L$. albida $\mathrm{K} 97-0003^{\mathrm{T}}$ (Supplementary Fig. S2b, available in IJSEM Online), but the predominant polar lipids of strain $\mathrm{KZ} 0017^{\mathrm{T}}$ differed from those of L. albida $\mathrm{K} 97-0003^{\mathrm{T}}$ in terms of the higher proportion of diphosphatidylglycerol and hydroxyphosphatidylethanolamine.

The cell wall of strain $\mathrm{KZ} 0017^{\mathrm{T}}$ contained meso- $\mathrm{A}_{2} \mathrm{pm}$, 3$\mathrm{OH} \mathrm{A}_{2} \mathrm{pm}, \mathrm{D}$-glutamic acid, glycine and L-alanine. The peptidoglycan type according to Schleifer \& Kandler (1972) was A1 $\gamma$. Whole-cell sugars of $\mathrm{KZ} 0017^{\mathrm{T}}$ contained xylose, mannose, galactose, rhamnose and ribose, but not arabinose. The acyl type of the cell-wall polysaccharides was glycolyl. Mycolic acids were absent. The major menaquinones were MK-10 $\left(\mathrm{H}_{4}\right)$ and MK-10 $\left(\mathrm{H}_{6}\right)$; MK$10\left(\mathrm{H}_{8}\right)$ was detected as a minor component. Most features with regard to the cell-wall components and quinone profile supported the affiliation of strain $\mathrm{KZ} 0017^{\mathrm{T}}$ to the genus Longispora (Matsumoto et al., 2003). However, the whole-cell sugar pattern of strain $\mathrm{KZ} 0017^{\mathrm{T}}$ differed from that of L. albida $\mathrm{K} 97-0003^{\mathrm{T}}$ in terms of the absence of arabinose and the presence of rhamnose, and the presence of mannose and ribose as minor components.

$16 \mathrm{~S}$ rRNA genes were amplified by PCR with a bacterial domain-specific primer set, 27F/1492R (Wang et al., 2007). PCR was performed on a T1 Thermocycler (Biometra) with Ex Taq polymerase (Takara-shuzo). The PCR protocol included: an initial denaturation period of 4 min at $94{ }^{\circ} \mathrm{C}$; 30 cycles of $94{ }^{\circ} \mathrm{C}$ for $1 \mathrm{~min}, 55^{\circ} \mathrm{C}$ for $1 \mathrm{~min}$ and $72{ }^{\circ} \mathrm{C}$ for $1 \mathrm{~min}$; $72{ }^{\circ} \mathrm{C}$ for $3 \mathrm{~min}$; and incubation at $4{ }^{\circ} \mathrm{C}$ until further processing. The nearly complete 16S rRNA gene sequence of strain $\mathrm{KZ}_{0017^{\mathrm{T}}}$ (1417 bp) was determined by a direct method using a BigDye terminator v3.1 cycle sequencing kit on an ABI 3130 Genetic Analyzer (Applied Biosystems). Analysis of sequence data was performed by using the MEGA version 3.1 software package (Kumar et al., 2004), after multiple alignment of the sequences by CLUSTAL $\mathrm{W}$ (Thompson et al., 1994) and SeaView (Galtier et al., 1996). Phylogenetic trees were constructed using the neighbourjoining (Saitou \& Nei, 1987) and maximum-parsimony (Fitch, 1971) methods. Bootstrap analysis (1000 replications) was carried out to evaluate the topology of the resulting tree (Felsenstein, 1985). An evolutionary distance matrix for the neighbour-joining method was generated according to the Kimura two-parameter model (Kimura, 1983).

The 16S rRNA gene sequence of strain $\mathrm{KZ} 0017^{\mathrm{T}}$ was compared with those from GenBank/EMBL/DDBJ using the program BLAST (http://blast.ncbi.nlm.nih.gov/Blast.cgi). The sequence similarity of strain $\mathrm{KZ} 0017^{\mathrm{T}}$ to the type strain of $L$. albida was $96.4 \%$ indicating that strain $\mathrm{KZ} 0017^{\mathrm{T}}$ represents a novel species in the genus Longispora (Stackebrandt \& 
Goebel, 1994). The neighbour-joining tree based on $16 \mathrm{~S}$ rRNA gene sequences, which was also supported by the maximum-parsimony method, showed that strain KZ0017 ${ }^{\mathrm{T}}$ fell in the cluster of the family Micromonosporaceae and formed a monophyletic cluster with L. albida $\mathrm{K} 97-0003^{\mathrm{T}}$ (Fig. 1).

Strain $\mathrm{KZ} 0017^{\mathrm{T}}$ differed from L. albida $\mathrm{K} 97-0003^{\mathrm{T}}$, its closest relative, in terms of growth characteristics and colony colour on several ISP media, temperature and $\mathrm{pH}$ ranges for growth, substrate utilization patterns and DNA $\mathrm{G}+\mathrm{C}$ content (Table 1). In addition, strain $\mathrm{KZ} 0017^{\mathrm{T}}$ was sensitive to $1.5 \%(\mathrm{w} / \mathrm{v}) \mathrm{NaCl}$, whereas L. albida K97-0003 was not. Furthermore, fatty acid and polar lipid profiling clearly differentiated strain $\mathrm{KZ} 0017^{\mathrm{T}}$ from L. albida
K97-0003 ${ }^{\mathrm{T}}$ (see Supplementary Table S1 and Supplementary Fig. S2, available in IJSEM Online).

On the basis of the data presented, it is proposed that strain $\mathrm{KZ} 0017^{\mathrm{T}}$ represents a novel species of the genus Longispora, for which the name Longispora fulva sp. nov. is proposed.

\section{Description of Longispora fulva sp. nov.}

Longispora fulva (ful'va. L. fem. adj. fulva tawny, yellowish brown, the colour of the colonies).

Cells are Gram-positive, non-acid-fast, aerobic and nonmotile. Straight chains of spores are formed on the top of short sporophores branching from the substrate mycelium. Spores are cylindrical $(0.25-0.35 \times 0.5-0.75 \mu \mathrm{m})$ and

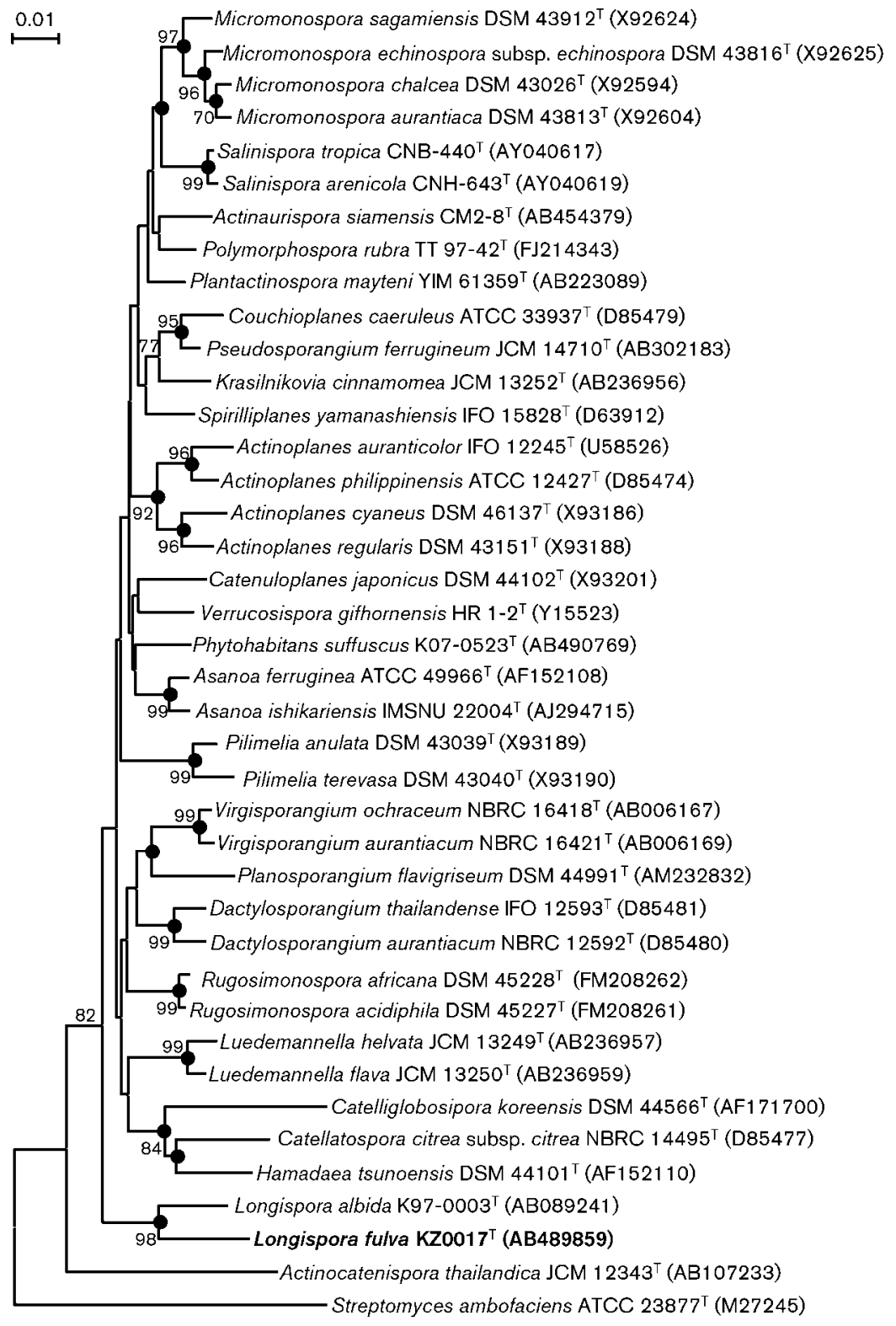

Fig. 1. Neighbour-joining phylogenetic tree based on 16S rRNA gene sequences showing the relationship between strain $K Z 0017^{\top}$ and the type strains of related genera in the family Micromonosporaceae. Numbers at nodes are bootstrap values (expressed as percentages of 1000 resampled datasets; only values $>70 \%$ are shown). Branching points supported by the maximum-parsimony method are indicated by closed circles. Bar, 0.01 substitutions per nucleotide position. 
exhibit a smooth surface. Grows at $10-33{ }^{\circ} \mathrm{C}$ and $\mathrm{pH} 6.0$ 8.5; optimum growth is at $28-30{ }^{\circ} \mathrm{C}$ and $\mathrm{pH}$ 6.5-7.5. The salinity $(\mathrm{NaCl})$ range for growth is $0-1.2 \%(\mathrm{w} / \mathrm{v})$; optimum growth is in $0-0.4 \%(\mathrm{w} / \mathrm{v}) \mathrm{NaCl}$. No growth is seen in the presence of $1.5 \%(\mathrm{w} / \mathrm{v}) \mathrm{NaCl}$. Utilizes (+)-Dglucose, inositol, xylose and sucrose as sole carbon sources. Does not grow on $(+)$-L-arabinose, fructose, $(+)$-Dmannitol, melibiose, $(+)$-raffinose or rhamnose. Melanoid pigment is not produced. Negative for $\mathrm{H}_{2} \mathrm{~S}$ production and nitrate reduction. Positive for hydrolysis of casein and starch, but negative for hydrolysis of gelatin, cellulose, xylan and chitin. Mycolic acids are absent. The cell wall contains meso- $\mathrm{A}_{2} \mathrm{pm}, 3-\mathrm{OH} \mathrm{A}_{2} \mathrm{pm}$, D-glutamic acid, glycine and L-alanine. Xylose, rhamnose and galactose are detected as the major whole-cell sugars; minor components are mannose and ribose. The acyl type of the cell-wall muramic acid is glycolyl. The major isoprenoid quinones are MK$10\left(\mathrm{H}_{4}\right)$ and MK-10 $\left(\mathrm{H}_{6}\right)$; MK- $10\left(\mathrm{H}_{8}\right)$ is a minor component. The major fatty acids are iso- $\mathrm{C}_{16: 0}, 10$-methyl- $\mathrm{C}_{17: 0}$ and iso- $\mathrm{C}_{17: 1} \omega 9 c$. The predominant polar lipids are diphosphatidylglycerol, phosphatidylethanolamine, hydroxyphosphatidylethanolamine and phosphatidylinositol; several unknown lipids and glycolipids are detected as minor components.

The type strain is $\mathrm{KZ} 0017^{\mathrm{T}}\left(=\mathrm{NBRC} 105670^{\mathrm{T}}=\mathrm{DSM}\right.$ $\left.45356^{\mathrm{T}}\right)$, isolated from soil collected at a group of old zelkova trees in Ohnuma, Fukushima, Japan. The genomic $\mathrm{G}+\mathrm{C}$ content of the type strain is $70.7 \mathrm{~mol} \%$.

\section{Emended description of the genus Longispora Matsumoto et al. 2003}

The description is as given by Matsumoto et al. (2003) with the following amendments. Galactose and xylose are the major sugars in whole-cell hydrolysates; arabinose, rhamnose, mannose and ribose may be detected. The diagnostic phospholipids are diphosphatidylglycerol, phosphatidylethanolamine and phosphatidylinositol (phospholipid type II). In addition, hydroxyphosphatidylethanolamine and several unknown lipids and glycolipids may be present. The major cellular fatty acids are iso- $\mathrm{C}_{16: 0}, 10$-methyl- $\mathrm{C}_{17: 0}$ and iso- $\mathrm{C}_{17: 1} \omega 9 \mathrm{c}$ (fatty acid type $3 \mathrm{~b}$ ).

\section{Acknowledgements}

We would like to thank Dr P. Meyers and the two anonymous referees for insightful comments. We also thank Dr Tomoko Aizawa and Yayoi Sakiyama (NITE) for their advice on polar lipid analysis and helpful discussions, and Shoichi Amano for his assistance with microscopic observations. This study was supported by the High-tech Research Center Project of the Ministry of Education, Culture, Sports, Science and Technology, Japan, and a research grant (2009-2011) of the Institute for Fermentation, Osaka, Japan.

\section{References}

Bartholomew, J. W. \& Mittwer, T. (1952). The Gram stain. Bacteriol Rev 16, 1-29.
Becker, B., Lechevalier, M. P. \& Lechevalier, H. A. (1965). Chemical composition of cell-wall preparations from strains of various formgenera of aerobic actinomycetes. Appl Microbiol 13, 236-243.

Chiba, H., Inokoshi, J., Okamoto, M., Asanuma, S., Matsuzaki, K., Iwama, M., Mizumoto, K., Tanaka, H., Oheda, M. \& other authors (2001). Actinohivin, a novel anti-HIV protein from an actinomycete that inhibits syncytium formation: isolation, characterization, and biological activities. Biochem Biophys Res Commun 282, 595-601.

Chiba, H., Inokoshi, J., Nakashima, H., Ōmura, S. \& Tanaka, H. (2004). Actinohivin, a novel anti-human immunodeficiency virus protein from an actinomycete, inhibits viral entry to cells by binding high-mannose type sugar chains of gp120. Biochem Biophys Res Commun 316, 203-210.

Felsenstein, J. (1985). Confidence limits on phylogenies: an approach using the bootstrap. Evolution 39, 783-791.

Fitch, W. M. (1971). Toward defining the course of evolution: minimum change for a specific tree topology. Syst Zool 20, 406-416.

Galtier, N., Gouy, M. \& Gautier, C. (1996). SEAVIEW and PHYLO_WIN: two graphic tools for sequence alignment and molecular phylogeny. Comput Appl Biosci 12, 543-548.

Gordon, R. E., Barnett, D. A., Handerhan, J. E. \& Pang, C. H.-N. (1974). Nocardia coelica, Nocardia autotrophica, and the nocardin strain. Int J Syst Bacteriol 24, 54-63.

Hamada, M. (2001). Cultural, physiological and biochemical characteristics in actinomycetes. In Identification Manual of Actinomycetes, 1st edn, Chapter 2, pp. 37-47. Edited by S. Miyadoh, M. Hamada, K. Hotta, T. Kudo, A. Seino, K. Suzuki \& A. Yokota. Tokyo: Business Center for Academic Societies Japan.

Harper, J. J. \& Davis, G. H. G. (1979). Two-dimensional thin-layer chromatography for amino acid analysis of bacterial cell walls. Int $J$ Syst Bacteriol 29, 56-58.

Hasegawa, T., Takizawa, M. \& Tanida, S. (1983). A rapid analysis for chemical grouping of aerobic actinomycetes. J Gen Appl Microbiol 29, 319-322.

Hayakawa, M. \& Nonomura, H. (1989). A new method for the intensive isolation of actinomycetes from soil. Actinomycetologica 3, 95-104.

Hopwood, D. A., Bibb, M. J., Chater, K. F., Kieser, T., Bruton, C. J., Kieser, H. M., Lydiate, D. J., Smith, C. P., Ward, J. M. \& Schrempf, H. (1985). Preparation of chromosomal, plasmid and phage DNA. In Genetic Manipulation of Streptomyces. A Laboratory Manual, pp. 7274. Edited by D. A. Hopwood, M. J. Bibb, K. F. Chater, T. Kieser, C. J. Bruton, H. M. Kieser, D. J. Lydiate, C. P. Smith, J. M. Ward \& H. Schrempf. Norwich: John Innes Foundation.

Kawamoto, I., Oka, T. \& Nara, T. (1981). Cell wall composition of Micromonospora olivoasterospora, Micromonospora sagamiensis, and related organisms. J Bacteriol 146, 527-534.

Kimura, M. (1983). The Neutral Theory of Molecular Evolution. Cambridge: Cambridge University Press.

Komagata, K. \& Suzuki, K. (1987). Lipid and cell-wall analysis in bacterial systematics. Methods Microbiol 19, 161-207.

Kroppenstedt, R. M. (1985). Fatty acid and menaquinone analysis of actinomycetes and related organisms. In Chemical Methods in Bacterial Systematics (Society for Applied Bacteriology Technical Series vol. 20), pp. 173-199. Edited by M. Goodfellow \& D. E. Minnikin. London: Academic Press.

Kumar, S., Tamura, K. \& Nei, M. (2004). MEGA3: integrated software for molecular evolutionary genetics analysis and sequence alignment. Brief Bioinform 5, 150-163.

Matsumoto, A., Takahashi, Y., Shinose, M., Seino, A., Iwai, Y. \& Ōmura, S. (2003). Longispora albida gen. nov., sp. nov., a novel genus of the family Micromonosporaceae. Int J Syst Evol Microbiol 53, 1553-1559. 
Munsell Color Co. Inc. (1976). Munsell Book of Color - Matte Finish Collection. Baltimore: Munsell Color Co., Inc.

Nishijima, M., Araki-Sakai, M. \& Sano, H. (1997). Identification of isoprenoid quinones by frit-FAB liquid chromatography-mass spectrometry for the chemotaxonomy of microorganisms. J Microbiol Methods 28, 113-122.

Rayner R. W. (1970). A Mycological Colour Chart. Kew, UK: Commonwealth Mycological Institute \& British Mycological Society.

Saitou, N. \& Nei, M. (1987). The neighbor-joining method: a new method for reconstructing phylogenetic trees. Mol Biol Evol 4, 406425.

Schleifer, K. H. \& Kandler, O. (1972). Peptidoglycan types of bacterial cell walls and their taxonomic implications. Bacteriol Rev 36, 407-477.

Shirling, E. B. \& Gottlieb, D. (1966). Methods for characterization of Streptomyces species. Int J Syst Bacteriol 16, 313-340.

Stackebrandt, E. \& Goebel, B. M. (1994). Taxonomic note: a place for DNA-DNA reassociation and $16 \mathrm{~S}$ ribosomal-RNA sequence analysis in the present species definition in bacteriology. Int J Syst Bacteriol 44, 846-849.
Tamaoka, J. \& Komagata, K. (1984). Determination of DNA base composition by reversed-phase high-performance liquid chromatography. FEMS Microbiol Lett 25, 125-128.

Thompson, J. D., Higgins, D. G. \& Gibson, T. J. (1994). CLUSTAL W: improving the sensitivity of progressive multiple sequence alignment through sequence weighting, position-specific gap penalties and weight matrix choice. Nucleic Acids Res 22, 4673-4680.

Tomiyasu, I. (1982). Mycolic acid composition and thermally adaptative changes in Nocardia asteroides. J Bacteriol 151, 828-837.

Uchida, K. \& Aida, K. (1977). Acyl type of bacterial cell wall: its simple identification by a colorimetric method. J Gen Appl Microbiol 23, 249-260.

Ueda, K., Tagami, Y., Kamihara, Y., Shiratori, H., Takano, H. \& Beppu, T. (2008). Isolation of bacteria whose growth is dependent on high levels of $\mathrm{CO}_{2}$ and implications of their potential diversity. Appl Environ Microbiol 74, 4535-4538.

Wang, X., Hoefel, D., Saint, C. P., Monis, P. T. \& Jin, B. (2007). The isolation and microbial community analysis of hydrogen producing bacteria from activated sludge. J Appl Microbiol 103, 1415-1423. 